\title{
Applying the chronicle workshop as a method for evaluating participatory interventions
}

\author{
Poulsen, Signe; Ipsen, Christine; Gish, Liv \\ Published in: \\ International Journal of Human Factors and Ergonomics
}

Publication date:

2015

Document Version

Peer reviewed version

Link back to DTU Orbit

Citation (APA):

Poulsen, S., Ipsen, C., \& Gish, L. (2015). Applying the chronicle workshop as a method for evaluating participatory interventions. International Journal of Human Factors and Ergonomics, 3(3/4), 271-290.

\section{General rights}

Copyright and moral rights for the publications made accessible in the public portal are retained by the authors and/or other copyright owners and it is a condition of accessing publications that users recognise and abide by the legal requirements associated with these rights.

- Users may download and print one copy of any publication from the public portal for the purpose of private study or research.

- You may not further distribute the material or use it for any profit-making activity or commercial gain

- You may freely distribute the URL identifying the publication in the public portal

If you believe that this document breaches copyright please contact us providing details, and we will remove access to the work immediately and investigate your claim. 
Applying the Chronicle Workshop as a method for evaluating participatory interventions

First author (Corresponding author)

Signe Poulsen, Post. Doc., PhD

Department of Management Engineering

Technical University of Denmark

Produktionstorvet, Building 424

DK-2800, Kgs. Lyngby

Denmark

E-mail: sipo@dtu.dk

Phone: +45 45256032

\section{Second author}

Christine Ipsen, Associate Professor, PhD

Department of Management Engineering

Technical University of Denmark

Produktionstorvet, Building 424

DK-2800, Kgs. Lyngby

Denmark

E-mail: chip@dtu.dk

Phone: +45 45256014

\section{Third author}

Liv Gish, Researcher, $\mathrm{PhD}$

Department of Management Engineering

Technical University of Denmark

Produktionstorvet, Building 424

DK-2800, Kgs. Lyngby

Denmark

E-mail: ligi@dtu.dk

Phone: +45 45254796 


\begin{abstract}
Despite the growing interest for process evaluation in participatory interventions, studies examining specific methods for process evaluation are lacking. In this paper, we propose a new method for process evaluation--the Chronicle Workshop. The Chronicle Workshop has not previously been used in intervention studies. The method was tested in three small and medium-sized companies. Four to six employees participated in each Chronicle Workshop, which was the last activity of the participatory preventive intervention program PoWRS. The program aims at creating changes which have a positive effect on both productivity and well-being.

In all cases we saw that the Chronicle Workshop gave valuable information about the intervention process and that it initiated a joint reflection among participants from different departments. The Chronicle Workshop makes it possible to better understand the results of the intervention, the factors affecting it, and the outcome evaluation based on a summary view of the company and interventionrelated factors that influence the intervention program and results.
\end{abstract}

\title{
Keywords:
}

Participatory interventions, process evaluation, small and medium-sized enterprises, evaluation method 


\section{Introduction}

Participatory intervention studies have been emphasized as a potential approach to alleviate workrelated stress (Kompier, Geurts, Grundemann, Vink, \& Smulders, 1998). From the beginning, participatory intervention study researchers have focused mainly on outcome evaluation to establish whether the intervention had any effect (Lamontagne, Keegel, Louie, Ostry, \& Landsbergis, 2005; Landsbergis \& Vivona-Vaughan, 1995; Parkes \& Sparkes, 1998). Applied psychology is the outset for outcome evaluations, but as Cox and colleagues (2007) argue, the traditional experimental approach from applied psychology is inadequate because it does not capture the continuously changing complexity in organisations. Their argument is supported by Semmer (2006), who states that many interventions fail because of implementation problems.

The outcome evaluation shows only whether the intervention has been successful in relation to the parameters included in the outcome evaluation; the evaluation does not, therefore, reveal any reasons for the specific result of the outcome evaluation. The outcome evaluation contributes information about whether or not the intended actions have had an effect, but it does not give information about how and why the intervention was successful or failed. Outcome evaluation therefore falls short when determining what effect different components of the intervention have had. The need for a process evaluation is thus suggested (Cox, Karanika, Griffiths, \& Houdmont, 2007). The process evaluation does not replace the outcome evaluation, but serves as a supplement in order to gain additional knowledge about the intervention and its mode of action. The process evaluation mind-set thereby also addresses another intervention problem--that the intervention at times is implemented differently than intended, also referred to as lack of fidelity (Carroll et al., 2007).

Despite the growing interest for process evaluation, studies examining specific methods for process evaluation are lacking. In this paper, we propose a new method for process evaluation, the Chronicle Workshop (CW). In the $\mathrm{CW}$, participants' intervention experience unfolds in a structured process in which time is combined with intervention outcome and affecting factors so as to illustrate the chronology of the events. This provides a deeper insight into the link between intervention process and outcome. We present and discuss the findings from using the $\mathrm{CW}$ in three companies as a process evaluation method, and we show how this approach corresponds with the outcome evaluation.

A participatory intervention study in three Danish small and medium-sized enterprises (SMEs) provides the empirical data for the present paper. The three companies are either IT or manufacturing companies. All companies implemented the same participatory intervention program, known as the 
PoWRS program (Ipsen et al., 2015) and tested its applicability. The program consists of three phases and focuses on changing the work characteristics in a participatory process. The aim of the program is to improve employee well-being by developing and implementing organisational-level changes in a process where the content of the intervention program is adapted to the local context of the workplace.

\section{Process evaluation}

Kompier and colleagues (2000) criticise the lack of emphasis put on the contextual and process variables in the evaluation research field. Intervention evaluation has its outset in clinical interventions where the primary focus has been on outcome. Consequently researchers have overlooked contextual and process factors. Steckler and Linnan (2002) define process evaluation as the "focus on the extent to which the intervention was implemented with the content, accuracy, coverage and quality that was planned." This strict focus on the intervention, particularly on intervention components and outcome, limits our understanding of the social mechanisms happening in organisations, including autonomy in decision-making (Kompier et al., 2000).

To get deeper insight into what works to ensure successful outcomes of organisational-level health interventions than the processes and factors identified by Nielsen et al. (2010), researchers in occupational health therefore focus both on the intervention components and outcome, as well as the social mechanisms (Bauer \& Jenny, 2013).

Discussions about process evaluation in literature are primarily concerned with what process evaluation should cover. Murta and colleagues (2007) acknowledge Steckler and Linnan's approach to process evaluation, and build upon their approach by suggesting that process evaluation should cover context, reach, dose delivered, dose received, fidelity, implementation, recruitment, and participants' attitude toward the intervention. Further, they argue that the link between process evaluation and outcome evaluation has not been thoroughly addressed (Murta, Sanderson, \& Oldenburg, 2007). In addition, Nielsen and colleagues (2010) argue that there is evidence that it is beneficial to integrate process and outcome evaluation. The argument is that in this combination it is possible to increase the knowledge of how and why interventions work (Nielsen, Randall, Holten, \& Gonzalez, 2010). Another paper (Nielsen and Randall, 2013) argues that process evaluation should (1) provide feedback to improve interventions, (2) replicate interventions in other settings to minimize pitfalls associated with a given intervention, (3) interpret the outcomes of interventions, and (4) help to conclude on the generalization, applicability and transferability of intervention 
studies. A recent paper stated that the process evaluation should cover stakeholders' readiness for change, motives, perceptions and awareness of the intervention (Biron \& Karanika-Murray, 2014).

The specific methods for process evaluation have not been reported thoroughly. Some have argued that quantitative methods are beneficial because they can confirm hypotheses (Randall, Griffiths, \& Cox, 2005). Others argue that a combined qualitative and quantitative approach is most suitable (Nielsen \& Abildgaard, 2013; Nielsen \& Randall, 2013) because it both identifies the change mechanisms and gives cross-validated and triangulated results. Egan et al. (2009) argue that they find qualitative methods much more suitable for process evaluation, as they provide more rich and insightful information about the data than what they believe the quantitative methods can.

According to Egan et al. (2009), the quantitative methods provide checklist data, but that is not the most interesting information when the aim is to investigate the relationship between implementation and outcome. The qualitative data appeared to uncover information that could explain the negative outcomes in some intervention studies (Egan, Bambra, Petticrew, \& Whitehead, 2009).

The analytical approach to the qualitative data in process evaluation has been criticised for being too unstructured, and the robustness of the findings thereby becomes unclear (Roen, Arai, Roberts, \& Popay, 2006). The Chronicle Workshop (CW), however, is a suggestion of a process-evaluation tool which, based on a structured process, investigates the relationship between changes and outcome. The CW aims at unfolding the participants' intervention experience in a structured process by combining time, intervention outcome and contextual factors. In this paper, we examine how the CW can help provide knowledge about contextual factors and their effect on an intervention. By contextual factors, we mean the internal and surrounding business context influencing the intervention. We examine the CW by applying it in three SMEs and analyzing the results. The CW is an example of a qualitative method intended for researchers, and in the present intervention study it has been combined both with other qualitative methods (such as interviews) and quantitative methods (such as surveys), and is conducted in the last phase of the PoWRS program (See Figure 1).

\section{The Chronicle Workshop - Theoretical background}

The Chronicle Workshop (CW) was initially developed as a change management method. The aim was to portray a particular time period of several years in a specific organisation to create a common understanding of the organisation among its members (Limborg \& Hvenegaard, 2011). Initially it 
was the intention that the $\mathrm{CW}$ could be used before a change process was started because the $\mathrm{CW}$ ideally would initiate discussion about norms and values in the organisation in relation to future changes.

There are two parts in a CW: 1) developing a timeline and 2) creating a coherent story and linking the story to future developments. The first part of a CW consists of three rounds--each round has a specific question related to the round. The questions can vary depending on the focus of the workshop. The first question is the most open and could be about important events in the organisation over a fixed period of time. The next two questions narrow the field and could ask about important persons, dilemmas or issues in the period. The participants write their answers on small notes, one answer per note. The subjective experiences reported on the notes are collected and a timeline is developed. For each round of questions, the participants are given paper notes in different colours, which make it possible to detect which notes refer to which round.

The participants then create a coherent story. First, the participants are asked to split the timeline into chapters, and each chapter is given a title (a metaphor or a humorous phrase). In the second part of a $\mathrm{CW}$, the participants are asked to analyse a particular time period with the aim of identifying supporting factors as well as obstructive factors.

The CW has been applied in studies of OHS management (Hohnen \& Hasle, 2011), organisational social capital (Sørensen, Hasle, \& Pejtersen, 2011), psychological work environment (Hvid, Lund, \& Pejtersen, 2008), and in working life studies (Gensby, 2014). One of the positive aspects of a CW is that it facilitates a process whereby shared norms and values become visible (Sørensen et al., 2011). Furthermore it provides contextual insights on organisational structures and it becomes a forum whereby the participants create mutual understandings and common explanations (Gensby, 2014). Comparing the $\mathrm{CW}$ to the focus group interview method, the $\mathrm{CW}$ has the advantage that all participants make a contribution with their notes. In the focus group interviews, some participants can become dominating, thus making other participants say very little (Mansell, Bennett, Northway, Mead, \& Moseley, 2004). In the CW, there is room for all the participants to give their input because they have already written it on the paper notes, which therefore become a way for them to engage in the discussion.

\section{Adjusting the Chronicle Workshop}

The idea of using the Chronicle Workshop $(\mathrm{CW})$ as a process evaluation tool as part of the intervention program emerged because it had proven to be beneficial when trying to understand and 
evaluate an intervention process in a project-based organisation(Grex \& Ipsen, 2010). The reason for using the $\mathrm{CW}$ in preventive interventions was to get a total picture (total $=$ time, outcome and contextual factors, i.e. the internal and surrounding business context influencing the intervention) based on qualitative approach.

In order to use the $\mathrm{CW}$ as a process evaluation tool in the context of an intervention, some adjustments were made. The most obvious adjustment is that the last part of the $\mathrm{CW}$, creating a coherent story, is omitted. This adjustment is made because the CW focused only on the intervention period, which we considered to be too short and too present to analyse.

The overall principle behind the CW is to create a space in which the participants' narratives are given an equal voice. In the focus group interview there is an interest in looking at the interaction between the participants and how they react to each other's viewpoints. The CW works as a mapping of the different participants' viewpoints, giving each participant an equal voice. The questions in the CW should function as a funnel, where the first question gives each of the participants the opportunity to mention whatever they remember from the last six months. It would also give an indication of whether the intervention had settled itself as an independent event. The first question asked in the CW was: Which important changes have occurred during the last six months that have affected your work? The second question was developed in order to gain information about what the participants actually remembered as part of the intervention. The second question was: Which important changes in your work have you discovered in relation to the intervention? The third question should reveal obstacles, as well as drivers for the intervention. The third question was: Which factors have impacted the interventions? We decided to give the participants ten minutes in each round to write their answers. The CW provides a summary view of the company and intervention-related factors that influence the intervention program and results. In combination with the facilitator interviews, it provides the basis for a validation of the results of the intervention.

\section{Method}

\section{The intervention program}

The PoWRS program is a participatory, primary preventive intervention program and combines both quantitative and qualitative approaches, as suggested by Nielsen and Randall (2013).

Originally it was developed for and tested in large companies (Ipsen \& Andersen, 2013) with the aim of improving employee well-being by developing and implementing organisational-level changes. Based on these results, the PoWRS program was then modified to fit the conditions of SMEs and tested 
in four Danish SMEs (Ipsen et al., 2015) still aiming to develop and implement organisational-level changes. Primary preventive interventions target sources of stress and well-being in the workplace through changes in the workplace or the organisation, i.e. organisational level changes (Hurrell \& Murphy, 1996). This approach is chosen because primary preventive interventions address workrelated problems which can result in work-related stress, for example work hours, procedures, performance measures, role ambiguities or conflicts in responsibilities.

The underlying idea behind the program is that the best result of an organisational-level change is reached when both management and employees have been involved in the entire process--hence it is a participatory program. The program aims at creating changes which have a positive effect on both productivity and well-being. Furthermore, the program tested whether employees with no facilitator training could be appointed as in-house facilitators to lead the process.

The intervention program consists of three phases. In the first phase, the need for an intervention is assessed and a project group is constituted. The project group consists of a project manager and two in-house facilitators.

In the second phase, the intervention starts. First the work and the workplace are explored by conducting two FishBone workshops (Ishikawa, 1986; Sørensen, 2010). One workshop is held for employees and one for the line and team managers. Focus in the FishBone workshops is: what excites and stresses the employees in their work. All statements are then clustered into themes, followed by a "Multi-Voting" session (Gray, Brown, \& Macanufo, 2010; Jungk \& Müllert, 1981) in which both employees and managers assign priorities to the suggested themes. The vote results in a prioritized list of five themes representing organisational-level changes to be initiated. These two sessions make the basis for a final decision on which two changes the worksite will focus on during the intervention. The decision on the final two changes is based on two main criteria: backing from the employees and feasibility within the given work conditions.

The intervention is initiated with a Kick-Off event about two weeks later. The event signals the beginning of the intervention. The changes are now implemented during the coming months by employees and managers. Everyone participates in the intervention and the changes are integrated into existing activities at the worksite. Parallel to the implementation, employees and managers are interviewed by the project group during which time views and opinions related to the interventions can be made clear. The results of the interviews are presented at department meetings and, subsequently, the implementation of the changes is discussed and adjusted among all the participants. In the third phase, the Chronicle Workshop (CW) is conducted with continuous evaluations and 
adjustments to the changes.

An overview of the intervention activities can be found in Figure 1.

(Insert Figure 1 here)

\section{The participating companies}

Four companies participated in the intervention program. In all four companies, managers wanted to improve the well-being of the employees and initiate changes, while preserving a focus on productivity. The four companies were all SMEs, but they worked in two different industries: two IT and two manufacturing companies. As part of the intervention program, each company identified two changes it wanted to focus on during the process. Only three companies completed all three phases. The fourth company decided to cancel the $\mathrm{CW}$ and the final survey because of the surrounding business context. This negatively influenced the intervention. The data material for this paper therefore relies on the results from three cases that completed the intervention. Where this paper addresses the findings from using the $\mathrm{CW}$ as a process evaluation tool, the overall results of the intervention have been reported in Ipsen et al. (2015). Information about the three companies participating in the $\mathrm{CW}$ can be found in Table 1.

(Insert Table 1 here)

\section{The Chronicle Workshop}

The company project groups appointed the participants for the workshop. The project groups were asked to find participants who were not part of the project group. All participants should be employees with no managerial responsibility. There should be both employees who had worked in the company for a long time and newly-hired employees among the participants. We asked for newly-hired employees because they might see the company differently since they have not been part of it for very long. We also asked for at least one participant from each department in the company. In addition to the selection criteria from us, the project group also had to consider which employees they could spare in operations while the $\mathrm{CW}$ was conducted. It was not the intention to make the participants in the $\mathrm{CW}$ representative of the entire company. We wanted to gain in-depth understanding from the employees about how they had perceived the period when the intervention had occurred.

In Company 1, six employees participated in the CW; in Company 2, four employees participated; 
and in Company 3, five employees participated (see Table 2 for more information about the CW participants). The first author facilitated each of the CWs and the two co-authors were observers.

(insert Table 2 here)

The CW began with a short introduction. The participants were told that everything was important to us, as a reminder to not hold back answers. Further, they were informed about the process and they had time to ask questions if something was unclear to them.

The participants were presented with the first question: Which important changes have occurred during the last six months that have affected your work? Then the participants used approximately ten minutes to write as many notes as possible, each with one important change on it. After ten minutes, all notes were gathered and then one-by-one read aloud by the facilitator. Each note was then explained by the participant who had written it. Afterwards the other participants commented on it. Each note was put onto a timeline (from the first month of the intervention to the last) after it had been explained and discussed. After the first question, the two following questions were facilitated in the same manner with paper notes: 2) Which important changes in your work have you discovered in relation to the two interventions? and 3) Which factors have impacted the interventions? After the three rounds we gave time for some general comments about the intervention and also about the CW. Overall we used about 11/2-2 hours for the $\mathrm{CW}$, including a break.

In general, we observed that more-educated employees (at IT companies) produced more notes by themselves in the CW. In the case from the manufacturing industry, with skilled workers, the participants did not make as many notes by themselves. It was clear that they had more input than what had been written; therefore the facilitator ended up writing notes for the participants if new things came up during the discussions.

\section{Outcome evaluation}

The intervention was also evaluated on its outcome. The outcome survey was made independently of the process evaluation. Since the PoWRS program is a process tool, the outcome differed among the three companies depending on their chosen changes. The outcome evaluation was made by surveying all the participating employees after the intervention ended. In the survey they were asked: How would you describe the change you have experienced in relation to Change 1? The same question 
was asked for Change 2. They were given a scale with five options (from no change to very big change).

\section{Analysis procedure}

The data from the CWs were analysed in a coding session with the three authors of this paper. Initially the notes from all the $\mathrm{CW}$ questions from all three company timelines were clustered in categories based on an inductive approach (Bryman, 2008). The aim of the categorization across the companies was to identify reasons for the specific results of the intervention. Besides the cross-case analysis, the $\mathrm{CW}$ notes were also analysed to identify case-specific outcomes. Examples of how the timeline notes were coded into categories are presented in the Results section.

\section{Results and analysis}

In the first round the participants were asked: Which important changes have occurred during the last six months that have affected your work? In two of the CWs, the participants actually referred directly to the intervention process in this round. In all three CWs, the participants had written notes about some of the activities related to the intervention. In the cases where the participants referred directly to the intervention, one or two of the participants remembered the intervention as such. The mentioned activities relate to the activities the companies themselves had developed and formulated to support the two organisational-level changes.

In the second round the participants were asked: Which important changes in your work have you discovered in relation to the two interventions? The notes to this question were characterized by reporting on different activities, such as weekly meetings or that the manager now said "good morning" to everyone before she went to her office. The arguments on the notes stated primarily that positive activities and/or comments affected the participants' jobs. We could also observe that in some cases one of the intervention changes was more significant in the eyes of the participants because they wrote many notes about one change and very few on the other change. In the third and final round the participants were asked: Which factors have impacted the interventions? The participants had many views on factors affecting the interventions, and across cases it became clear that the in-house facilitators, to a high degree, were associated with the interventions and the changes. Also the project manager was mentioned as an important factor. In two of the cases, the participants also included factors such as management support, that they were able to bill the hours spent on the project on a project number, and that they had been very busy with other tasks during the intervention. 
A simplified version of the final results from one of the CWs is documented in Figure 2. The timeline worked well in structuring the answers from Questions 1 and 2, but with Question 3, it was more difficult to place the answers on the timeline. The main reason for the difficulty in placing the red notes on the timeline was that the answers often referred to factors that had affected the process during the entire process or to general conditions which were also difficult to assign to a specific point in time.

(insert Figure 2 here)

\section{Across cases}

The timeline (Question 1), combined with Question 3 (Which factors have impacted the interventions?), and the explanations from the Chronicle Workshop (CW) participants made it possible to identify general factors which had an impact on the interventions across the three cases. Table 3 shows how the factors were developed from the statements in the $\mathrm{CW}$ to the overall categories.

(insert Table 3 appr. here)

In all cases we could see that the $\mathrm{CW}$ gave valuable information about the intervention process. The process information was either very case-specific or of a more general form. What characterized the process information was that the brief statement written on the note was elaborated on by the participants, and in this elaboration the different meanings ascribed to the process information became clear. We identified four common factors across the cases: managerial support, the internal facilitators, busyness, and the possibility to participate.

\section{Managerial Support}

In the $\mathrm{CW}$ the theme managerial support was stated both positively and negatively. For instance in Companies 2 and 3, respondents had different opinions about whether there had been management support and about the type of management support. In Company 2, the participants all found that there had been support from top management, but the $\mathrm{CW}$ revealed differences between whether the participants found that the middle managers had supported the process. The participants also explained what the supporting middle manager had done in order to support the process, which included 
formulating how the changes could become relevant, and prioritizing how to use time in meetings to support the changes.

\section{Internal facilitators}

The CW participants all highlighted the internal facilitators as persons who had influenced the process. Some participants just wrote the name of one of the internal facilitators, and they argued that in their point of view it was this person in particular who had been very engaged in the process. Besides the internal facilitators' general engagement in the process, the participants emphasized the different activities the internal facilitators had initiated. In Company 1 , one of the internal facilitators was mentioned on more notes than the other. The explanations following the notes showed that he had been very visible during the process and the $\mathrm{CW}$ participants therefore had an understanding of him as very engaged in the process. In Company 3, opinions differed about one of the internal facilitators--some found her very enthusiastic, but others commented on the explanations about her enthusiasm and said that they thought she had not contributed positively to the intervention process. Their explanations revealed that some participants actually found her to be part of one of the problems in the company, a problem that the company was addressing in the intervention.

\section{Busyness}

There were several notes about busyness in each of the CWs. In Company 3 the participants expressed that due to management dispositions, the busyness had been handled differently than previously and therefore the employees had not felt that the busyness had had a negative impact on the intervention. In Company 2, busyness and the demand to keep a high billing rate were mentioned as important factors in order to understand why the intervention did not have an effect in two of the departments. In particular, the strong management focus on keeping a high billing rate was perceived to have an impact on internal development projects. In Company 1, the participants stated that they had been busy, but the participants did not reflect upon whether this had affected the intervention.

\section{Possibility to participate}

The last theme mentioned at all of the CWs was about the involvement in the intervention process. In the discussions about the notes, a few participants across the cases said that they had not been able to participate in the FishBone workshop. Therefore they did not necessarily agree with the chosen changes and felt less involved than the rest of the $\mathrm{CW}$ participants. 


\section{Case-specific changes}

The Chronicle Workshops (CW) also revealed some case-specific changes. The results of the second question--Which important changes in your work have you discovered in relation to the intervention?--are presented in Table 4 and show the case-specific changes resulting from the interventions and the two initiated changes (Table 1) in each company.

(insert Table 4 appr. here)

\section{Company 1}

In Company 1, the case-specific changes were: development of better project management, better communication between manager and employees and between employees, and more feedback. Two of the changes were actually the two chosen changes in the intervention (project management and feedback and recognition). The $\mathrm{CW}$ showed what the participants included when they talked about the two changes. Project management included many things which indicated that the participants thought that project management was now much better. These things were: more project managers, clear communication about who was assigned to which projects, and a stricter scrum approach. With regard to feedback and recognition, some of the participants reflected that it was not only about them receiving feedback from the manager, but it was also about giving feedback to their colleagues. Finally, the CW gave rise to a discussion about how the communication between the employees had improved; some argued that they thought there was a clear link to the intervention change on feedback.

\section{Company 2}

In Company 2, it was difficult to detect changes that were common for all the participating departments because the different departments made their own interpretation of the chosen changes. The changes for this company are therefore not necessarily a theme that all departments have mentioned. The changes were: better knowledge-sharing, the University project, and increased focus on the handover of tasks between colleagues. Two of the CW participants worked in the department that was most positive about the outcome of the intervention. These two participants both said that they had developed better knowledge-sharing, and they mentioned the specific tools and approaches that had affected their perception of better knowledge-sharing. The CW participants from the other two departments wrote notes in which they referred to the intervention as "the University project." In the 
elaboration of the notes, it was clear that the two departments had not taken ownership of the intervention--they just saw it as a research project. Despite the lack of ownership of the intervention, several of the participants mentioned that they had become much more aware of the handover process to their colleagues.

\section{Company 3}

The changes in Company 3 were: change in management style, more awareness of different personality traits among the employees, and better cooperation. All CW participants wrote a note stating that their manager had changed management style. Most of the notes were positive, but a few wrote that even though they had observed a change, it was not sufficient. Some of the notes referred to differences in personality traits. When the notes were explained, it turned out that the employees had been through a personality test in relation to how they communicated with each other. This test had been an eyeopener for many of the participants because they became aware that their colleagues could understand a comment differently than it was intended. Finally, some of the notes in the $\mathrm{CW}$ referred to better cooperation between the two departments. When these notes were discussed, it turned out that in one of the departments they thought that the cooperation had increased, but in the other department there was not the same perception.

\section{The links and missing links between process evaluation and outcome evaluation}

The CWs gave a very broad and differentiated picture of the intervention process. The results from the CW could therefore, in some cases, explain the results from the surveys (outcome evaluation) (See Table 5).

(insert table 5 here)

In Company 1, the surveys showed that more than $60 \%$ of the employees found that there had been big changes in relation to the change in project management. More than $60 \%$ had experienced moderate changes in relation to the change in recognition and feedback. This corresponds well with the findings from the $\mathrm{CW}$, where all participants wrote notes about better project management. In the $\mathrm{CW}$, not all of the participants actively wrote notes about more recognition and feedback, suggesting that this change did not have as much impact as the other change.

In Company 2, more than $30 \%$ had not experienced any change in relation to one of their changes 
(well-defined tasks) and $50 \%$ had experienced at least a moderate change in the other change (collegiate spirit, unity and feedback). In the $\mathrm{CW}$ it was clear that there were great differences between the different departments. To protect anonymity, the survey did not ask which department the respondent worked in, so it was not possible to detect this difference among the departments from the surveys. However, the CW not only clearly showed the differences but also explained why there were differences.

In Company 3, the survey showed that $70 \%$ experienced at least moderate changes in relation to the change in more cooperation and team spirit. In the other change in management style, $18 \%$ experienced no change, whereas the rest of the employees experienced at least a small change. These results were also reflected in the $\mathrm{CW}$. We also got explanations for why some employees did not detect any change in relation to management style.

The timeline in the CW adds information about other events that happened during the intervention period. These events are not being directly linked to the intervention, but when analysing the intervention process, it adds some information to the understanding of the intervention process. For instance in Company 2, they told us they had been busy, and the $\mathrm{CW}$ also revealed that the company had undergone a certification process during the intervention period. The participants in the $\mathrm{CW}$ did not link the certification process with busyness, but it was valuable information because it showed that there had been many other things happening at the same time as the intervention. In both Company 1 and Company 3, they included whether employees had been hired or fired during the intervention period. This information also adds to the understanding of the atmosphere in the company while the intervention was ongoing.

\section{Discussion}

The Chronicle Workshop $(\mathrm{CW})$ is a process evaluation tool not previously applied in intervention studies. The $\mathrm{CW}$ provides a narrative approach to process evaluation where the employees themselves are given the opportunity to express what course of events, actors or conditions have been important for them. Thereby the $\mathrm{CW}$ provides an employee perspective to the evaluation and creates an understanding of "the processes that facilitated the change" (Nielsen \& Randall, 2013) according to the employees. In this study the $\mathrm{CW}$ is a backward-looking approach that is suitable to use to gain rich information about the how's and why's when trying to understand outcome evaluations. Using the $\mathrm{CW}$ discloses what the employees have perceived as drivers and barriers for the process. This 
process information is valuable in order to understand the outcomes of the interventions, as well as when researchers plan new interventions. As a process evaluation tool, the $\mathrm{CW}$ results are relevant if the PoWRS intervention program is to be used again, but the $\mathrm{CW}$ results also point to some general themes that are valuable when designing a new intervention program. The method proves to provide information about contextual issues (Nielsen \& Randall, 2013), as well as moderators and mediators in the intervention processes (Biron \& Karanika-Murray, 2014).

Looking at the method and its requirements, there are two crucial concerns: What requirements are there for the researchers if they want to use the CW? What does the tool require from the participants? For the researchers, the requirements do not differ much from other qualitative methods, such as interviews and focus group interviews. As with the focus group interviews, the $\mathrm{CW}$ requires that the researcher who facilitates the $\mathrm{CW}$ is very aware of the participants. We detected a difference between the companies in relation to the number of notes produced by the participants. The method therefore requires a facilitator who is able to identify if there are any participants who are uncomfortable writing notes themselves so that the facilitator can assist in writing extra notes.

For the participants, the $\mathrm{CW}$ does not require any preparation. The fact that the participants could see what knowledge they produced during the process was a very positive outcome of the method. The visibility creates more transparency for the participants than interviews and surveys because they can see their own contributions as well as their colleagues' contributions. The timeline also becomes a good way of keeping focus on what is relevant because the participants and the facilitator continuously need to take the timeline into consideration.

Nielsen (2013) argues that a formative evaluation involving both employees and managers is beneficial in order for employees to be active during the intervention. However, the formative approach does not take the power relation between the managers and employees into account. A disadvantage of the suggestion from Nielsen (2013) is that because the managers are in a more powerful position than the employees, the employees might not give their true point of view because of the fear of potential consequences for them. In the $\mathrm{CW}$, the employees have the possibility to give their point of view without needing to worry about power relations.

Another important result of the $\mathrm{CW}$ is that the participants obtain new realisations because the process promotes joint reflection. In all three companies, the $\mathrm{CW}$ initiated a joint reflection between participants from different departments. In Company 2, the fact that one department had succeeded 
in making meaningful changes had not been clear to all the participants in the CW. The CW therefore initiated a joint reflection about how and why this one department had succeeded. In Company 3 , the theme of change in management style was elaborated upon by all participants. In the $\mathrm{CW}$ the participants realised that perceptions of the management style varied. They discussed why these differences existed. The CW was not only a room for joint reflection, but also a place for learning, where the tacit knowledge from one participant became externalized (Nonaka \& Takeuchi, 1995) and thereby accessible to the other participants. In a recent study (Gensby, 2014) in which the CW was used as it was originally intended, the CW also created learning among the participants. In our study we can see that there is a potential for learning. Though it was not detectable in the CW in Company 1 , still, we argue that the $\mathrm{CW}$ can create learning among the participants.

\section{Outcome evaluation}

The CW made it possible to better understand the results of the intervention and the outcome evaluation. Looking at the survey results it can be difficult to see if there have been differences within the company, i.e. if one department has been successful and the other departments have not. The surveys were anonymous, and since the study was completed in small and medium-sized companies, we could not ask about gender, department and title because that would have made it possible to trace the informants. In the $\mathrm{CW}$ it became very clear if such differences existed because participants represented each department. The differences were clear when the participants answered Questions 2 and 3 because the participants who had experienced a positive change wrote positive statements on the notes, whereas the other participants wrote negative notes or no notes at all.

\section{Implications, limitations and conclusion}

The weakness of the Chronicle Workshop $(\mathrm{CW})$ is that it does not directly create added value for the company, although it proves to be a possible way to create joint reflection. The strengths of the $\mathrm{CW}$ are that it: employs a narrative approach, assesses the usability of the intervention program, is an efficient tool, and validates other types of data. The challenge is to create an open atmosphere where the participants feel comfortable writing about their experiences and opinions on paper.

A limitation is that the CW can become a consensus-establishing platform (Gensby, 2014), and participants therefore keep critical comments to themselves. This is a valid point, although it might be more common when using the $\mathrm{CW}$ in its original form. This limitation requires the facilitator of the CW to keep asking questions, such as "Does everyone agree with this?" in order to ensure that 
critical viewpoints are brought forward.

When asking the project group to find participants, a risk might be psychological barriers between some of the participants. We did not detect this, but it is important for the $\mathrm{CW}$ facilitator to be aware of whether some of the participants seem uncomfortable during the $\mathrm{CW}$.

It is important to specify that there are some limitations related to the number of participants in the $\mathrm{CW}$. There should be participants from each department and preferably more than one participant from each in order to get comprehensive information. Further, fewer than four participants will also be a limitation because it can be questioned whether the timeline will be comprehensive.

To conclude, our results show that the Chronicle Workshop can be used as a process evaluation tool in preventive organisational interventions by providing a summary view of the company and intervention-related factors that influence the intervention program and results. The Chronicle Workshop also gives input into what should be included and excluded in new intervention projects.

References

Bauer, G.F. \& Jenny G.J (2013) Salutogenic organisations and change - The concepts behind organisational health interventions research. Springer.

Biron, C., \& Karanika-Murray, M. (2014). Process evaluation for organisational stress and wellbeing interventions: Implications for theory, method, and practice. International Journal of Stress Management, 21(1), 85-111. doi:10.1037/a0033227

Bryman, A. (2008). Social research methods (3. ed.). Oxford University Press.

Carroll, C., Patterson, M., Wood, S., Booth, A., Rick, J., \& Balain, S. (2007). A conceptual framework for implementation fidelity. Implementation Science : IS, 2, 40. doi:10.1186/1748$5908-2-40$

Cox, T., Karanika, M., Griffiths, A., \& Houdmont, J. (2007). Evaluating organisational-level work stress interventions: Beyond traditional methods. Work \& Stress, 21(4), 348-362.

Egan, M., Bambra, C., Petticrew, M., \& Whitehead, M. (2009). Reviewing evidence on complex social interventions: appraising implementation in systematic reviews of the health effects of organisational-level workplace interventions. Journal of Epidemiology \& Community Health, 63(1), 4-11. 
Gensby, U. (2014). Assessing the Present in Perspective of the Past: Experiences from a Chronicle Workshop on Company-Level Work Disability Management. Nordic Journal of Working Life Studies, 4(2), 85-115.

Gray, D., Brown, S., \& Macanufo, J. (2010). Gamestorming: a playbook for innovators, rulebreakers, and changemakers (Vol. 1. ed.). Beijing: O'Reilly.

Grex, S., \& Ipsen, C. (2010). The Chronicle Workshop - A method to explore and enhance innovative processes in project-based organisations. In International Conference on Organisational Learning (pp. 1-15).

Hohnen, P., \& Hasle, P. (2011). Making work environment auditable - A "critical case" study of certified occupational health and safety management systems in Denmark. Safety Science, 49(7), 1022-1029. doi:10.1016/j.ssci.2010.12.005

Hurrell, J. J., \& Murphy, L. R. (1996). Occupational stress intervention. American Journal of Industrial Medicine, 29(4), 338-41. doi:10.1002/(SICI)1097-0274(199604)29:4<338::AIDAJIM11>3.0.CO;2-2

Hvid, H., Lund, H., \& Pejtersen, J. (2008). Control , flexibility and rhythms. Scandinavian Journal of Work Environment \& Health, (6), 83-90.

Ipsen, C. \& Andersen, V., (2013). A multi-level and participatory model for prevention of workrelated stress in knowledge work. In: Bauer, G., Jenny, G. (Eds.), Salutogenic Organisations and Change: The Concepts Behind Organisational Health Intervention Research, 1st ed. Springer, 127-149.

Ipsen, C., Gish, L. \& Poulsen, S. (2015). Organisational-level interventions in small and mediumsized enterprises: Enabling and inhibiting factors in the PoWRS program. Safety Science, 71, 264-274. doi: 10.1016/j.ssci.2014.07.017

Ishikawa, K. (1986). Guide to Quality Control (Vol. 2nd editio). Tokyo, Japan: Quality Resources.

Jungk, R., \& Müllert, N. R. (1981). Zukunftswerkstätten. Mit phantasie gegen routine und resignation [Future workshops. With fantasy towards routine and resignation]. Hamburg: Hoffmann und Campe.

Kompier, M. A. J., Cooper, C. L., \& Geurts, S. A. E. (2000). A multiple case study approach to work stress prevention in Europe. European Journal of Work \& Organisational Psychology, 9(3), 371-400. doi:10.1080/135943200417975

Kompier, M. A. J., Geurts, S. A. E., Grundemann, R. W. M., Vink, P., \& Smulders, P. G. W. (1998). Cases in stress prevention: the success of a participative and stepwise approach. Stress and Health, 14(3), 155-168.

Lamontagne, A. D., Keegel, T., Louie, A. M., Ostry, A., \& Landsbergis, P. a. (2005). A systematic review of the job-stress intervention evaluation literature, 1990-2005. International Journal of Occupational and Environmental Health, 13(3), 268-80. doi:10.1179/oeh.2007.13.3.268 
Landsbergis, P., \& Vivona-Vaughan, E. (1995). Evaluation of an occupational stress intervention in a public agency. Journal of Organisational Behavior, 16(1), $29-48$.

Limborg, H. J., \& Hvenegaard, H. (2011). The Chronicle Workshop - The use of narratives to reveal the story of a work community and understand its culture. In Facilitating Change Using interactive methods in organisations, communities and networks (pp. 305-325).

Mansell, I., Bennett, G., Northway, R., Mead, D., \& Moseley, L. (2004). The learning curve : the advantages and disadvantages in the use of focus groups as a method of data collection. Nurse Researcher, 11(4), 79-88.

Murta, S. G., Sanderson, K., \& Oldenburg, B. (2007). Process evaluation in occupational stress management programs. American Journal of Health Promotion, 21(4), 248-254.

Nielsen, K. (2013). Review Article: How can we make organisational interventions work? Employees and line managers as actively crafting interventions. Human Relations, 66(8), 1029-1050. doi:10.1177/0018726713477164

Nielsen, K., \& Abildgaard, J. S. (2013). Organisational interventions: A research-based framework for the evaluation of both process and effects. Work \& Stress, 27(3), 278-297. doi:DOI:10.1080/02678373.2013.812358

Nielsen, K., \& Randall, R. (2013). Opening the black box: Presenting a model for evaluating organisational-level interventions. European Journal of Work and Organisational Psychology, 22(5), 601-617. doi:10.1080/1359432X.2012.690556

Nielsen, K., Randall, R., Holten, A.-L., \& Gonzalez, E. R. (2010). Conducting organisational-level occupational health interventions: What works? Work and Stress, 24(3), 234-259.

Nonaka, I., \& Takeuchi, H. (1995). The knowledge creating company. New York: Oxford Univ Press.

Parkes, K. R., \& Sparkes, T. J. (1998). Organisational interventions to reduce work stress- are they effective? A review of the literature. Norwich England.

Randall, R., Griffiths, A., \& Cox, T. (2005). Evaluating organisational stress-management interventions using adapted study designs. European Journal of Work and Organisational Psychology, 14(1), 23-41. doi:10.1080/13594320444000209

Roen, K., Arai, L., Roberts, H., \& Popay, J. (2006). Extending systematic reviews to include evidence on implementation: methodological work on a review of community-based initiatives to prevent injuries. Social Science \& Medicine (1982), 63(4), 1060-71. doi:10.1016/j.socscimed.2006.02.013

Semmer, N. K. (2006). Job stress interventions and the organisation of work. Scandinavian Journal of Work Environment \& Health, 32(6), 515-527. doi:10.5271/sjweh.1056 
Steckler, A., \& Linnan, L. (2002). Process Evaluation for Public Health Interventions and Research. (A. Steckler \& L. Linnan, Eds.) (First edit.). San Fransisco, CA, USA: Jossey-Bass.

Sørensen, O. H. (2010). Fishbonemetoden: hvilke ben er der i den? Tidsskrift for Arbejdsliv, 12(1), 35-50. Retrieved from http://www.nyt-om-arbejdsliv.dk/images/pdf/2010/nr1/tfa1_2010_035050.pdf

Sørensen, O. H., Hasle, P., \& Pejtersen, J. H. (2011). Trust relations in management of change. Scandinavian Journal of Management, 27(4), 405-417. doi:10.1016/j.scaman.2011.08.003

Tables and figures

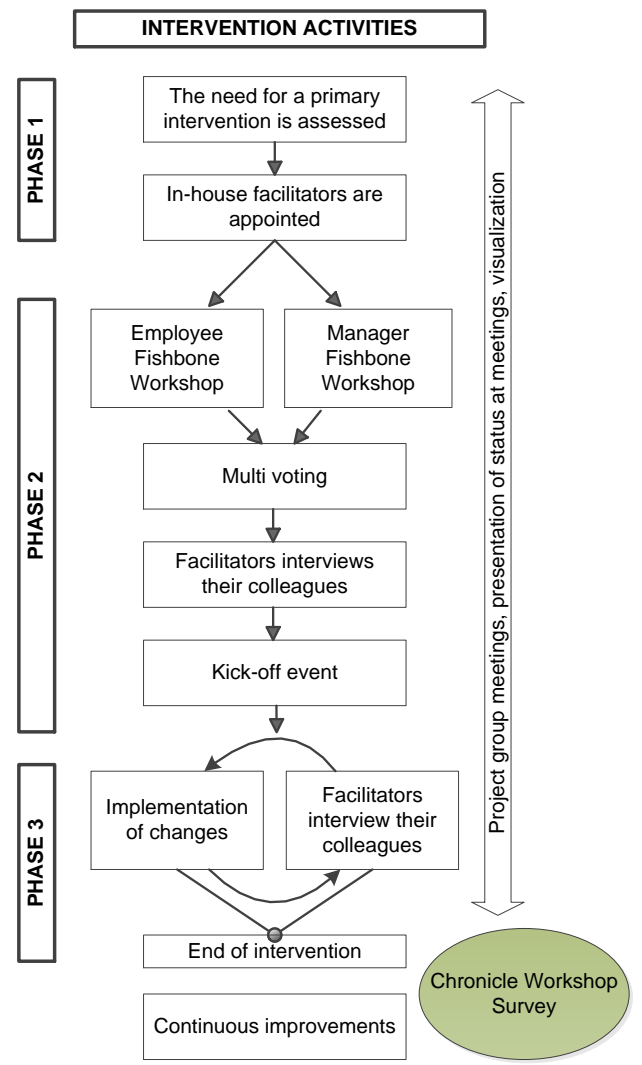

Figure 1: Overview of intervention activities (an elaborated version of this figure is printed in Ipsen et al., 2015) 


\begin{tabular}{|c|c|c|c|}
\hline & Company 1 & Company 2 & Company 3 \\
\hline Change 1 & Project management & Well-defined tasks & $\begin{array}{l}\text { More cooperation } \\
\text { and team spirit }\end{array}$ \\
\hline Change 2 & $\begin{array}{l}\text { Feedback and } \\
\text { recognition }\end{array}$ & $\begin{array}{l}\text { Collegiate spirit and } \\
\text { feedback }\end{array}$ & $\begin{array}{l}\text { Visible and } \\
\text { consistent } \\
\text { management }\end{array}$ \\
\hline Industry & IT & IT & Manufacturing \\
\hline $\begin{array}{l}\text { Number of } \\
\text { employees } \\
\text { (participating in the } \\
\text { intervention) }\end{array}$ & 31 & 37 & 36 \\
\hline $\begin{array}{l}\text { Number of } \\
\text { departments } \\
\text { participating in the } \\
\text { intervention }\end{array}$ & 2 & 3 & 2 \\
\hline Survey response rate & $\begin{array}{l}71 \%(22 \\
\text { respondents) }\end{array}$ & $\begin{array}{l}81 \%(30 \\
\text { respondents) }\end{array}$ & $\begin{array}{l}61 \%(22 \\
\text { respondents) }\end{array}$ \\
\hline
\end{tabular}

Table 1: Information about the participating companies

\begin{tabular}{|l|l|l|l|}
\hline & Company 1 & Company 2 & Company 3 \\
\hline $\begin{array}{l}\text { Number of } \\
\text { participants }\end{array}$ & 6 & 4 & 5 \\
\hline $\begin{array}{l}\text { Employment in the } \\
\text { company }\end{array}$ & $>1$ yr: 0 & $>1$ yr: 1 & $>1$ yr: 2 \\
$1-5$ yr: 2 & $1-5$ yr: 2 & $1-5$ yr: 0 \\
\hline Function & $\begin{array}{l}\text { IT developers and } \\
\text { supporters }\end{array}$ & $\begin{array}{l}\text { Administrative staff, } \\
\text { surveyors and IT } \\
\text { developers }\end{array}$ & $\begin{array}{l}\text { Blue-collar } \\
\text { (assembly) }\end{array}$ \\
\hline Gender & Men only & 3 men, 1 woman & 1 man, 4 women \\
\hline
\end{tabular}




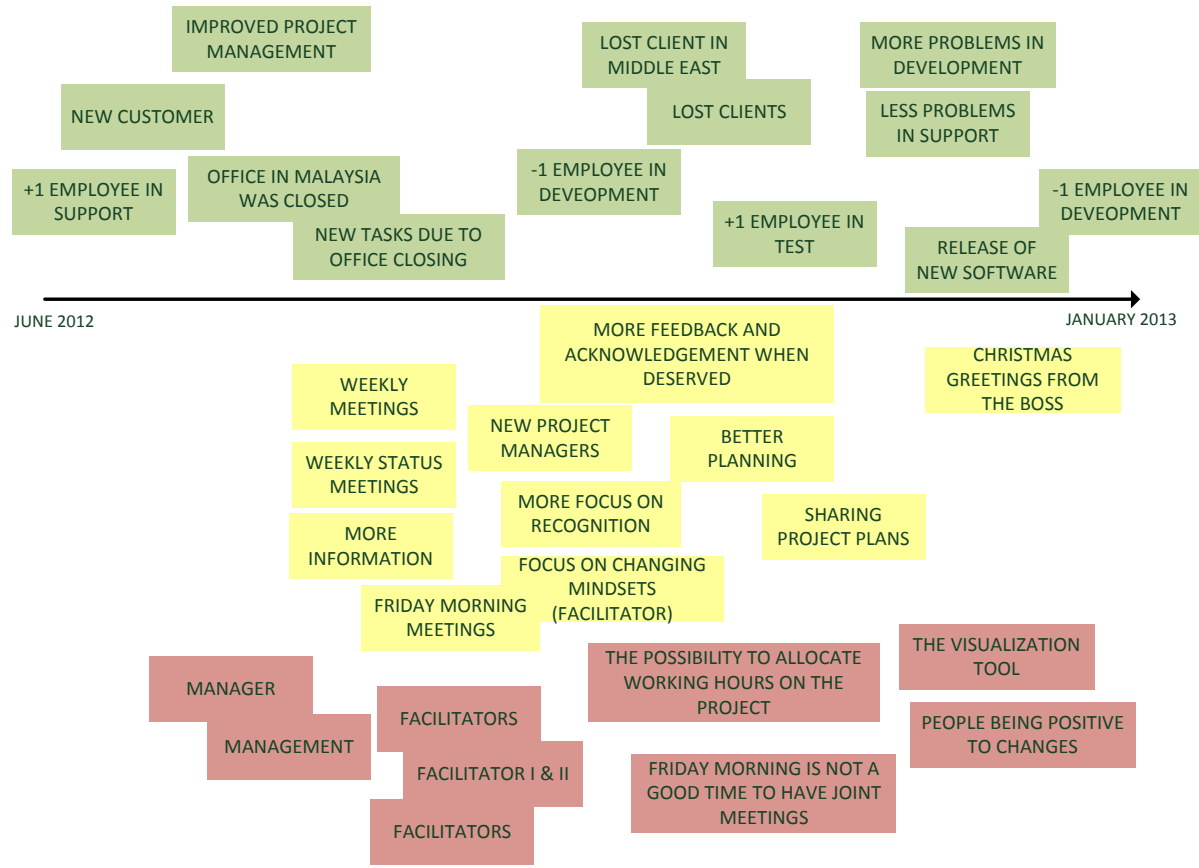

Figure 2: Simplified version of the result from one of the Chronicle Workshops in Company 1. Green question: 1) Which important changes have occurred during the last six months that have affected your work? Yellow question: 2) Which important changes in your work have you discovered in relation to the two interventions? Red question: 3) Which factors have impacted the interventions? 


\begin{tabular}{|c|c|c|c|}
\hline \multirow{2}{*}{\multicolumn{2}{|c|}{$\begin{array}{l}\text { Factors } \\
\text { Managerial support }\end{array}$}} & \multicolumn{2}{|c|}{ CW note (examples) } \\
\hline & & \multicolumn{2}{|c|}{$\begin{array}{l}\text { Manager/management (Company 1) } \\
\text { Management support (Company 2) } \\
\text { Manager (Company 3) }\end{array}$} \\
\hline \multicolumn{2}{|c|}{ Internal facilitators } & \multicolumn{2}{|c|}{ Facilitators (Company $1,2,3$ ) } \\
\hline \multicolumn{2}{|c|}{ Busyness } & \multicolumn{2}{|c|}{$\begin{array}{l}\text { New tasks due to office closing } \\
\text { (Company1) } \\
\text { Release of new software (Company 1) } \\
\text { Best financial result in the history of the } \\
\text { company (Company 2) } \\
\text { Overtime work (Company 3) }\end{array}$} \\
\hline \multicolumn{2}{|c|}{ Possibility to participate } & \multicolumn{2}{|c|}{$\begin{array}{l}\text { The possibility to allocate working hours on } \\
\text { the project (Company 1) } \\
\text { The employees' willingness to make } \\
\text { changes in the department (Company 2) } \\
\text { Everybody has affected the process } \\
\text { (Company 3) }\end{array}$} \\
\hline \multicolumn{4}{|c|}{$\begin{array}{l}\text { Table 3: Factors impacting the intervention across cases (Question 3). The CW note shows how the factors were developed in } t \\
\text { coding session. }\end{array}$} \\
\hline & \multicolumn{2}{|l|}{ Important changes } & CW note (examples) \\
\hline \multirow{3}{*}{ 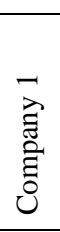 } & \multicolumn{2}{|l|}{ Development of better project management } & $\begin{array}{l}\text { Project management status meetings } \\
\text { New project managers }\end{array}$ \\
\hline & \multicolumn{2}{|l|}{ Better communication } & $\begin{array}{l}\text { Friday morning meetings } \\
\text { Focus on handing over projects }\end{array}$ \\
\hline & \multicolumn{2}{|l|}{ More feedback } & $\begin{array}{l}\text { More/Better feedback when deserved } \\
\text { More focus on recognition }\end{array}$ \\
\hline \multirow{3}{*}{ 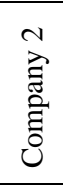 } & \multicolumn{2}{|l|}{ Better knowledge-sharing } & $\begin{array}{l}\text { Calling and receiving calls from colleagues } \\
\text { more often }\end{array}$ \\
\hline & \multicolumn{2}{|l|}{ The University project } & The University project \\
\hline & \multicolumn{2}{|l|}{$\begin{array}{l}\text { Increased focus on handover of tasks } \\
\text { between colleagues }\end{array}$} & $\begin{array}{l}\text { Handover of cases between departments } \\
\text { Calling colleagues more often }\end{array}$ \\
\hline & \multicolumn{2}{|l|}{ Change in management style } & $\begin{array}{l}\text { More visible management style } \\
\text { More consistent manager }\end{array}$ \\
\hline & \multicolumn{2}{|l|}{$\begin{array}{l}\text { Becoming aware of different personality } \\
\text { traits among the employees }\end{array}$} & $\begin{array}{l}\text { Course in communication } \\
\text { Personality test }\end{array}$ \\
\hline ¿ี & \multicolumn{2}{|l|}{ Better cooperation } & $\begin{array}{l}\text { The team is better at communicating with } \\
\text { each other }\end{array}$ \\
\hline
\end{tabular}

\begin{tabular}{|l|l|l|l|}
\hline & Company 1 & Company 2 & Company 3 \\
\hline
\end{tabular}




\begin{tabular}{|c|c|c|c|}
\hline Change 1 & Project management & Well-defined tasks & More cooperation and \\
\hline $\begin{array}{l}\text { How would you } \\
\text { describe the } \\
\text { change you have } \\
\text { experienced in } \\
\text { relation to change } \\
1\end{array}$ & $\begin{array}{l}\text { Very big change: } 4.5 \% \\
\text { Big change: } 59.1 \% \\
\text { Moderate change: } 13.6 \\
\% \\
\text { Small change: } 22.7 \% \\
\text { No change: } 0 \%\end{array}$ & $\begin{array}{l}\text { Very big change: } 0 \% \\
\text { Big change: } 13.3 \% \\
\text { Moderate change: } 30.0 \% \\
\text { Small change: } 20.0 \% \\
\text { No change: } 36.7 \%\end{array}$ & $\begin{array}{l}\text { team spirit } \\
\text { Very big change: } 9.1 \% \\
\text { Big change: } 31.8 \% \\
\text { Moderate change: } 27.3 \\
\% \\
\text { Small change: } 22.7 \% \\
\text { No change: } 9.1 \%\end{array}$ \\
\hline $\begin{array}{l}\text { Change } 2 \\
\text { How would you } \\
\text { describe the } \\
\text { change you have } \\
\text { experienced in } \\
\text { relation to change } \\
2\end{array}$ & $\begin{array}{l}\text { Feedback and } \\
\text { recognition } \\
\text { Very big change: } 0 \% \\
\text { Big change: } 9.1 \% \\
\text { Moderate change: } 54.5 \\
\% \\
\text { Small change: } 18.2 \% \\
\text { No change: } 18.2 \%\end{array}$ & $\begin{array}{l}\text { Collegiate spirit and } \\
\text { feedback } \\
\text { Very big change: } 3.3 \% \\
\text { Big change: } 13.3 \% \\
\text { Moderate change: } 33,3 \% \\
\text { Small change: } 30.0 \% \\
\text { No change: } 20.0 \%\end{array}$ & $\begin{array}{l}\text { Visible and consistent } \\
\text { management } \\
\text { Very big change: } 0 \% \\
\text { Big change: } 22.7 \% \\
\text { Moderate change: } 31.8 \\
\% \\
\text { Small change: } 27.3 \% \\
\text { No change: } 18.2 \%\end{array}$ \\
\hline
\end{tabular}

